\title{
IDENTITAS DAN POSISI PEREMPUAN DALAM ROMAN L'ENFANT DE SABLE KARYA TAHAR BEN JELLOUN
}

\author{
(Identity and Women Position in L'enfant De Sable \\ by Tahar Ben Jelloun) \\ Sunahrowi dan Gandis Prastiwi Damayanti \\ Universitas Negeri Semarang \\ Jalan Sekaran, Gunung Pati, Semarang, Jawa Tengah, Indonesia \\ Posel: sunahrowi@mail.unnes.ac.id \\ Posel: gandis_prastiwidamayanti@yahoo.com
}

\begin{abstract}
Abstrak: Identitas dan gender merupakan isu sensitif di dunia ketiga. Isu ini selalu berbenturan dengan sifat kultural manusianya dan sekaligus juga menjadi wilayah asing bagi mereka. Lakilaki dan perempuan menjadi sebuah posisi yang saling berlawanan. Mereka menempati tempat yang berbeda di masyarakat dunia ketiga. Perempuan secara kultural mendapat stereotip yang kurang menguntungkan bagi eksistensinya di hadapan laki-laki. Tahar Ben Jelloun, pengarang Prancis kelahiran Maroko, mampu mengambil dengan cukup cermat situasi yang berada di lingkungannya tersebut. Ia dalam roman yang berjudul L'Enfant de Sable mampu memberikan gambaran jelas tentang posisi dan identitas perempuan Aljazair dan sekaligus juga mengoposisikan dengan tokoh laki-laki. Ia yang lahir dari masyarakat dunia ketiga mampu menarik tema-tema ini ke dalam isu-isu poskolonial, utamanya tentang tema-tema perempuan dan eksistensinya di dalam masyarakat.
\end{abstract}

Kata Kunci: gender, identitas, posisi, feminisme, poskolonial

Abstract: Identity and gender are sensitive issues in the third world. This issue has always clashed with the cultural nature of human beings and also become a foreign territory for them. Both men and women become opposite positions. They occupy different places in third world society. Women are culturally stereotyped less favorable for existence in the presence of men. Tahar Ben Jelloun, a French-born Moroccan author, was able to take quite a careful situation in his neighborhood. He in the novel L'Enfant de Sable is able to provide a clear picture of the position and identity of Algerian women and at the same time also posing with male characters. He who was born of a third world society was able to draw these themes into poscolonial issues, primarily on the themes of women and their existence in society.

Keywords: gender, identity, position, feminism, postcolonial

\section{PENDAHULUAN}

Gender secara mendasar bukanlah sebuah pemisahan menurut jenis kelamin secara fisiologis, namun lebih merupakan pengelompokan yang secara kultural menciptakan stereotip-stereotip tertentu pada dua identitas tersebut. Sebagaimana sistem hubungan kekerabatan gender merupakan sebuah konstruksi kultural yang dibentuk dari seperangkat nilai yang dianut dalam masyarakat. Peran ritual yang diterapkan oleh masyarakat terhadap perempuan memunculkan subordinasi perempuan dalam masyarakat sekaligus membatasi ruang bagi perempuan. Pembatasan ini secara nirsadar telah mendefinisikan perempuan sebagai sosok yang pasif. 
Di satu sisi keluarga merupakan institusi di mana para anggotanya hidup dalam relasi yang memberikan dukungan psikologis dan cinta, namun di sisi lain, keluarga juga menjadi arena konflik antara kebutuhan akan hubungan yang mutualistis di antara anggotanya dengan edukasi seksis yang menempatkan perempuan pada posisi subordinat. Sebagai bagian dari institusi sosial keluarga juga memiliki peran ideologis yang menanamkan pemisahan peran antara laki-laki dan perempuan. Ada sejumlah nilai, norma, dan perilaku yang dengan tegas diterapkan kepada laki-laki namun tidak untuk perempuan. Demikian pula sebaliknya. Alih-alih melihat anak-anak sebagai seorang individu yang utuh orang tua sering kali mendorong anak perempuan untuk menjadi sosok yang feminin, sementara anak laki-laki menjadi sosok yang maskulin. Penyesuaian tersebut tidak hanya berdasarkan nilai dan norma sosial, namun sering kali berdasarkan pula pada nilai dan norma religi.

Bagi pemeluk agama Islam, Alquran merupakan sumber nilai dan norma religi yang utama. Alquran sebagai penuntun utama bagi pemeluknya, menyatakan dengan tegas bahwa laki-laki dan perempuan sejajar. Keduanya tunduk pada kewajiban religius yang tertera dalam kitab suci tersebut. Keduanya akan mendapat pahala atau siksa yang sama tergantung dari perbuatannya di dunia. Agama Islam sering diidentikkan dengan masyarakat yang patriarkal sehingga sebagian besar negara muslim sampai saat ini masih terikat pada struktur sosial yang bercirikan perbedaan kedudukan laki-laki dan perempuan. Sistem patriarki melegitimasi kedudukan ayah sebagai pemegang otoritas baik dalam kerangka hubungan ayah dan anak maupun dalam hubungan suami dan istri. Keluarga merupakan institusi pertama tempat nilai-nilai diproduksi dan diturunkan. Organisasi keluarga tradisional dan model keluarga besar diatur oleh prinsip hierarki dan prinsip otoritas. Prinsip-prinsip yang mengatur hubungan antara orang tua dan anak serta hubungan antara laki-laki dan perempuan juga hubungan antara anak sulung dan anak bungsu pada dasarnya sama, yaitu prinsip otoritas.

Di Maroko, sebuah negara muslim di Afrika Utara, ajaran Islam amat memengaruhi cara pandang, cara hidup, dan tradisi. Selain sebagai dogma, agama Islam terintegrasikan dalam kebudayaan dan praktik-praktik kebudayaan setempat dalam wujud sebagai sumber nilai-nilai utama. Masyarakat tradisional Maroko yang bersifat patriarkal diatur berdasarkan agama dan struktur sosial yang menekankan kepatuhan dan ketaatan sekaligus merepresentasikan laki-laki sebagai pihak yang memiliki kuasa, kontrol, dan superior dalam semua bidang baik dalam keluarga maupun dalam masyarakat. Sementara perempuan berada pada posisi yang berlawanan.

Kedudukan perempuan tersubordinasi dalam masyarakat patriarkal dan sebagai konsekuensinya perempuan dianggap sebagai warga masyarakat kelas dua. Pandangan ini begitu kuat sehingga memiliki anak perempuan bukanlah kebanggaan bagi keluarga, justru mendatangkan perasaan malu. Memiliki anak perempuan adalah aib yang mencoreng kehormatan keluarga.

Fenomena inilah yang diangkat dengan gamblang oleh Tahar Ben Jelloun, pengarang Prancis kelahiran Maroko, dalam roman yang berjudul L'Enfant de Sable. Tokoh utama roman yang terpaksa hidup dalam kepalsuan identitas yang diciptakan ayahnya untuk menutupi aib keluarga memaparkan dengan gemilang betapa masyarakat patriarkal amat berkuasa atas hidup seorang perempuan pada era poskolonial. 
Pengaruh Prancis mulai ada di Maroko sejak perang dunia pertama pada tahun 1912 sedangkan karya Sastra pertama dalam bahasa Prancis muncul pertama kalinya pada sekitar tahun 50an. Hal tersebut menunjukkan bahwa sejak lama penulis-penulis Maroko sudah peduli mengenai masalah-masalah sosial yang berhubungan dengan keadaan masyarakat yang tumbuh dalam budaya Arab patriarki dan muslim.

Dasar pandangan feminis poskolonial ini berakar pada penolakan universalitas pengalaman perempuan. Pengalaman perempuan yang hidup di negara dunia ketiga (koloni/bekas koloni) berbeda dengan perempuan berlatar belakang dunia pertama. Perempuan dunia ketiga menanggung beban penindasan lebih berat karena selain mengalami penindasan berbasis gender, mereka juga mengalami penindasan antarbangsa, suku, ras, dan agama. Dimensi kolonialisme menjadi fokus utama feminisme poskolonial yang pada intinya menggugat penjajahan baik fisik, pengetahuan, nilai-nilai, cara pandang, maupun mentalitas masyarakat. Kelahiran feminis poskolonial juga tak bisa dilepaskan dari konteks sejarah berakhirnya perang dunia kedua ditandai dengan lahirnya negara-negara baru yang terbebas dari penjajah Eropa lahirlah Feminisme Gelombang Kedua pada tahun 1960. Dengan puncak diikutsertakannya perempuan dalam hak suara parlemen. Tahun itu merupakan awal bagi perempuan mendapatkan hak pilih dan selanjutnya ikut mendiami ranah politik kenegaraan. Gelombang kedua ini dipelopori oleh para feminis Prancis seperti Helene Cixous (seorang Yahudi kelahiran Algeria yang kemudian menetap di Prancis) dan Julia Kristeva (seorang Bulgaria yang kemudian menetap di Prancis) bersamaan dengan kelahiran dekonstruksionis, Derrida. Dalam The Laugh of the Medusa, Cixous (1976) mengkritik logosentrisme yang banyak didominasi oleh nilai-nilai maskulin.

Kaum feminis kontemporer menaruh perhatian tertentu sehingga membedakannya dari kalangan nonfeminis dan feminis awal. Perhatian ini mengandung makna bahwa terdapat "pembagian kerja" sehingga segelintir feminis menjawabnya dengan perlawanan politik dan yang lain dengan cara lain pula. Berbagai pekerjaaan dan pengalaman hidup kaum feminis kontemporer menghasilkan aneka persepsi tentang realitas sosial dan penindasan perempuan. Keanekaragaman ini merupakan sumber kekuatan bagi gerakan pembebasan perempuan. Gelombang awal feminisme kadang-kadang dilihat melalui refleksi atas pengalaman perempuan kulit putih dari kalangan menengah ke atas. Perempuan kulit putih kelas menengah itu ditonjolkan secara kuat dalam gerakan perempuan kontemporer. Namun, perspektif ini ditantang oleh pandangan feminis poskolonialis yang mencerminkan pengalaman yang sangat berbeda dari perempuan kulit berwarna, perempuan kelas pekerja, dan sebagai-nya. Pengalaman yang sangat kaya dan beraneka ragam di kaum feminis poskolonial memberikan pandangan segar atas masalah penindasan terhadap perempuan dan menyajikan perspektif dan penilaian baru bagi gerakan pembebasan perempuan.

Feminis poskolonial meyakinkan dunia bahwa perempuan dunia ketiga tersubordinasi atas faktor berlapis, patriarki, kapitalisme, penjajahan fisik, hingga di dalam bahasa dan aktualisasi intelektualitas. Berabad lamanya perempuan di dunia ketiga tenggelam sebagai subaltern yang tidak memiliki politik agensi selama sebelum dan sesudah perang dunia kedua. Selama sebelum PD II banyak pejuang tanah terjajah Eropa yang lebih mementingkan kemerdekaan bagi laki-laki saja. Terbukti kebangkitan 
semua negara-negara terjajah dipimpin oleh elite nasionalis dari kalangan pendidikan, politik, dan militer yang semuanya adalah laki-laki. Pada era itu kelahiran feminisme gelombang kedua mengalami puncaknya, tetapi perempuan dunia ketiga masih dalam kelompok yang bisu. Dengan keberhasil-an gelombang kedua ini perempuan dunia pertama melihat bahwa mereka perlu menyelamatkan perempuan-perempuan dunia ketiga dengan asumsi bahwa semua perempuan adalah sama. Dengan asumsi ini perempuan dunia ketiga menjadi objek analisis yang dipisah dari sejarah kolonialisasi, rasisme, seksisme, dan relasi sosial. Kecenderungan feminisme liberal yang selalu melihat perempuan sebagai makhluk lemah tak berdaya dan korban laki-laki ini tidak dapat diterima oleh perempuanperempuan muda di bebe-rapa negara maju. Retorika feminisme yang melekat pada ibu-ibu mereka terutama di tahun 70-an di daratan Amerika dan Inggris telah membuat generasi muda bosan dengan feminisme. Feminisme seolaholah menjadi ukuran moralistik dan politik seseorang dan menjadi pergerakan kaum histeris serta sangat mudah untuk menuduh dan melabeli seseorang dengan atribut tidak feminis. Kelompok-kelompok perempuan muda yang kritis inilah yang kemudian memperjuangkan apa yang disebut feminis poskolonialis. Secara kritis kelompok feminis poskolonial ini melihat teks-teks ketertindasan perempuan dalam berbagai ranah. Selain itu kelompok ini tidak menekankan pada kesetaraan seperti kelompok liberal, yaitu identitas dan gender, tetapi lebih menekankan pada perbedaan yang tak diskriminatif. Di sini dapat dipahami jika aliran ini membawa paradigma baru dalam feminisme dari perdebatan seputar kesetaraan ke perdebatan seputar perbedaan.
Lebih jauh lagi menurut Carol Gilligan (2009), penekanan laki-laki terhadap keterpisahan dan otonomi mengarahkan mereka untuk mengembangkan suatu gaya penalaran moral (dan pemikiran) yang menekankan pada keadilan, ketidakberpihakan dan hak. Sebaliknya, penekanan perempuan pada hubungan dan keterkaitan mengerahkan mereka untuk mengembangkan gaya penalaran moral (dan pemikiran) yang menekankan pada keinginan, kebutuhan, dan kepentingan dari sekelompok orang tertentu. Berhipotesis bahwa gaya moral perempuan tidak lebih valid dari gaya moral laki-laki (pandangan khas feminis awal) Gilligan mengklaim bahwa karena kebanyakan ahli dalam teori perkembangan moral telah secara keliru menggunakan norma laki-laki sebagai norma manusia yang digunakan untuk mengukur perkembangan moral perempuan dan laki-laki. Kebanyakan ahli itu (menurut Gilligan) telah secara keliru menyimpulkan bahwa secara moral perempuan kurang berkembang dibandingkan laki-laki. Hal tersebut bukanlah merupakan suatu realitas. Gilligan berargumen bahwa bukan perempuan yang harus diubah, melainkan standar yang digunakan untuk menilai perkembangan perempuan sebagai manusia moral.

\section{METODE PENELITIAN}

Objek material dalam penelitian ini adalah roman l'Enfant de Sable karya Tahar Ben Jelloun (1995), sedangkan objek formal dalam penelitian ini adalah teori feminisme poskolonial. Penelitian ini diawali dengan studi pustaka untuk menemukan teori dan objek yang tepat serta mencapai tujuan yang ingin dicapai dalam penelitian. Metodologi penelitian dalam penelitian ini adalah metode deskriptif analitik. Whitney dalam Arikunto (2005, hlm. 60) menyatakan bahwa metode deskriptif adalah pencarian fakta dengan interpretasi yang tepat. 


\section{PEMBAHASAN}

L'Enfant de Sable adalah sebuah roman karya Tahar Ben Jelloun yang terbit pada tahun 1985 di Prancis. Roman ini mengungkapkan pesan tentang kondisi pasca kolonial di Maroko juga menekankan tema-tema yang berkaitan dengan pembangunan identitas individu. Roman ini juga dapat dilihat sebagai kritik atas tradisi Islam dan adat istiadat Maroko dengan referensi khusus, yaitu kedudukan perempuan.

Karya ini menceritakan bagaimana kehidupan seorang anak manusia bernama Ahmed (Zahra) yang terlahir perempuan. Akan tetapi, oleh tekanan sosial dan tradisi, sang ayah Hadj Ahmed menganggap dan membesarkan anak tersebut sebagai seorang laki-laki. Semua upacara yang dilakukan seperti khitanan dan pernikahan menggunakan cara dan adat seperti seorang laki-laki. Perbedaan kekuasaan dan kebebasan sebagian pihak yang ditekan menyebabkan terjadinya banyak pertentangan di antara pihak-pihak tersebut. Cerita di dalam roman L'Enfant de Sable tersebut merupakan cerita yang berasal dari seorang pendongeng dengan alur yang sedemikian menarik. Di sini Tahar Ben Jelloun mengkritisi permasalahan patriarki yang jika ditarik lebih dalam lagi permasalah yang tersebut adalah persamaan gender dan kesetaraan lakilaki dan perempuan untuk mendapatkan hak asasi manusia yang sama. Adat istiadat yang tecermin dalam roman tersebut merupakan pengaruh dari kolonisasi di era poskolonial.

Roman ini mengungkapkan adanya ketidaksetaraan gender dalam konteks dekolonisasi Maroko. Ketegangan antara nasionalis dan pejabat protektorat Prancis secara teratur melatarbelakangi roman ini. Bagian pertama dari roman ini menggambarkan upaya Hadj Ahmed (ayah Ahmed/Zahra) untuk menyem- bunyikan identitas sesungguhnya dari diri Ahmed, bahwa Ahmed sebenarnya adalah seorang perempuan. Ahmed merupakan anak ke-8 dari delapan bersaudara, yang semuanya adalah perempuan. Menurut tradisi yang berkembang di sana kurangnya anak laki-laki merupakan sesuatu yang memalukan. Maka dari itu, untuk menjaga martabat dan untuk menurunkan warisannya, Ahmed dipaksa untuk menjadi laki-laki.

Karena harus menjalani kehidupan sebagai seorang lelaki, Ahmed pun bahkan menikahi sepupunya (Fatima), seorang gadis penderita epilepsi yang sakit-sakitan dan pada akhirnya mati muda. Selama hidupnya Fatima sendiri dianggap sebagai kegagalan oleh keluarganya dan masyarakat. Ahmed mengakui bahwa hal tersebut dianggap sebagai penyakit (menyimpang). Dia melakukan itu bukan atas dasar cinta, melainkan demi kepentingan sosial dan untuk menutupi rahasianya.

Karakter ibu Ahmed mewujudkan keunggulan peran perempuan dalam masyarakat patriarkal. Dalam roman ini sang ibu memiliki karakter sebagai istri yang setia, patuh, dan selalu melayani suami. Namun, gambaran ini hanya mencerminkan penampilan. Sang ayah tidak benar-benar bahagia. Di satu sisi, ia melihat istrinya ini sebagai wanita yang cacat fisik karena tidak mampu memberikan seorang anak kepada suaminya yang akan menanggung namaNya dan akan mewarisi kekayaannya. Pada kenyataannya kelebihan istrinya bertentangan dengan kepentingannya sendiri: fakta bahwa sang istri taat terusmenerus dan berulang kali untuk mewujudkan keinginan suami justru membuatnya dalam kondisi buruk dan memperkuat kelemahannya. Ia berkata kepadanya,

"Tu es une femme de bien, épouse soumise, obéissante, mais au bout de ta 
septième fille, j'ai compris que tu portes en toi une infirmité: ton ventre ne peut concevoir d'enfant mâle, il est fait de telle sorte qu'il ne donnera-à perpétuitéque des femelles."

"Kamu adalah istri yang baik, istri patuh, taat, tetapi di akhir anak perempuan ketujuhmu, aku memahami bahwa kamu cacat : perutmu tidak dapat mengandung anak laki-laki, hal ini dibuat sehingga tidak akan memberikan seumur hiduphanya perempuan."

Anak-anak perempuan yang telah dilahirkan juga tidak memiliki hak istimewa. Mereka tidak memiliki kelayakan atas perhatian ayahnya karena mereka dianggap tidak berarti apa-apa.

\begin{abstract}
"Bien sûr tu peux me reprocher de ne pas être tendre avec tes filles. Elles sont à toi. Je leur ai donné mon nom. Je ne peux pas leur donner mon affection parce que je ne les ai jamais désirées."

"Tentu saja kamu dapat menegurku tidak cenderung pada anak-anak perempuanmu. Mereka adalah milikmu. Aku memberi mereka namaku. Aku tidak dapat memberi mereka rasa sayangku karena aku tidak pernah mengharapkan mereka."
\end{abstract}

Perlakuan terhadap Ahmed sangat berbeda dari ayanya. Dia tidak menerima sikap ayahnya terhadap saudara perempuannya, tetapi alasan karena dia diterima sesuai dengan perilaku dan kebiasaan masyarakat yang memperkuat keunggulan manusia sebagai seorang laki-laki. Akhirnya dia bersikap acuh tak acuh, tetapi tetap memiliki rasa kasih sayang. Ahmed menjauhkan diri dari mereka untuk menghargai mereka. Dia menghargai hidup yang berbeda yang telah dianugerahkan, bahkan oleh kebohongan.

Il avait décidé que son univers était à lui et qu'il était bien supérieur à celui de sa mère et de ses soeurs -en tout cas très différent. Il pensait même qu'elles n'avaient pas d'univers. Elles se contentaient de vivre à la surface des choses, sans grande exigence, suivant son autorité, ses lois et ses volontés.

Dia telah memutuskan bahwa dunianya adalah miliknya dan bahwa dia jauh lebih tinggi dari ibunya dan saudara-saudara perempuannya dalam setiap kasus yang sangat berbeda. Dia bahkan berpikir bahwa mereka tidak memiliki alam. Mereka hidup bahagia di permukaan keadaan, tanpa tuntutan yang besar, sesuai dengan kekuasaannya, undangundangnya dan keinginanya.

Il $m$ 'arrive encore d'imaginer quelle vie j'aurais eue si je n'avais été qu'une fille parmi les autres, une fille de plus, la huitième, une autre source d'angoisse et de malheur. Je crois que je n'aurais pas pu vivre et accepter ce que mes soeurs comme les autres filles dans ce pays subissent. Je ne crois pas que je suis meilleure, mais je sens en moi une telle volonté, une telle force rebelle, que j'aurais probablement tout chamboulé. Dia mendatangiku lagi menggambarkan kehidupan seperti apa yang aku miliki jika aku bukanlah seorang perempuan diantara yang lainnya, seorang perempuan yang lebih, kedelapan, sebuah sumber kecemasan lain dan kemalangan. aku kira bahwa aku tidak dapat hidup dan menerima saudara-saudara perempuanku seperti anak perempuan lain di negaranegara ini. Aku tidak mengira bahwa aku lebih baik, tetapi aku merasakan sebuah kemauan yang sama, sebuah kekuatan memberontak yang sama, yang aku mungkin memiliki kekecewaan.

Perempuan sebagai kaum pasif akan menerima nasib mereka selama kebe-radaan dominasi ayah. Mereka akan kehilangan warisan setelah kematian ayah, hal ini juga mengakibatkan iri dan kecemburuan dari pihak paman, akibat dari kesalahan ayah dan menimbulkan kesedihan di rumah.

...les filles restées à la maison dilapidèrent l'argent de l'héritage et cherchaient à nuire d'une façon ou d'une autre à leur frère caché, mais ce frère 
était hors d'atteinte; invisible, il continuait malgré tout de régner.

...anak perempuan tinggal di rumah menghamburkan uang warisan dan berusaha untukmencelakakan dengan sebuah cara atau lainnya untuk saudara mereka yang tersembunyi, tetapi saudara laki-laki itu diluar jangkauan, tidak terlihat, dia melanjutkan meskipun tetap memerintah.

Dapat ditemukan dua karakter perempuan dalam novel ini. Yang pertama adalah kepasifan, yaitu mereka yang dapat mendominasi dan pergi begitu saja tanpa mengenal kata "pemberontak", "protes", ataupun "menentang". Yang kedua lebih negatif dan serius, yaitu perempuan yang bertindak melawan kepentingan mereka sendiri dan orang lain bahwa mereka mengklaim untuk melindungi diri. Mereka bertanggung jawab untuk memperbaiki kondisi mereka. Ahmed merangkum situasi ini dalam keluarganya.

Enfin, inutile de vous rappeler que je suis un homme d'ordre et que, si la femme chez nous est inférieure à l'homme, ce n'est pas parce que Dieu l'a voulu ou que le Prophète l'a décidé, mais parce que'elle accepte ce sort. Alors subissez et vivez dans le silence.

Akhirnya, ketidakgunaan yang mengingatkan anda bahwa aku seorang pria pesanan dan bahwa, jika perempuan dirumah kami lebih rendah dari pria, tidak karena Tuhan menginginkannya atau nabi telah memutuskannya, tetapi karena dia menerima nasib ini. Kemudian menderita dan hidup dalam keheningan.

Ahmed (Zahra) menyadari, menganalisis dan memahami logika dimana dia berada, dia menyangkal dan secara aktif berpartisipasi. Dengan cara ini, dia meniru perilaku ibunya dan saudara-saudara perempuannya untuk menurut pada ayahnya, bukan karena rasa kagum tetapi karena pilihan. Dia lebih suka untuk menyangkal esensi sendiri daripada membuang-buang kesempatan ini untuk bebas, untuk menjalani kehidupan yang lebih sah daripada ibunya ataupun saudarasaudaranya. Dia berkata,

\begin{abstract}
"Le soir je m'endormais vite, car je savais que j'allais recevoir la visite de ces silhouettes que j'attendais, muni d'un fouet, n'admettant pas de les voir si épaisses et si grosses. Je les battais car je savais que je ne serais jamais comme elles, je ne pouvais pas être comme elles...C'était pour moi une dégénérescence inadmissible."

"Malam ini saya tidur lebih awal, karena aku tahu bahwa aku akan menerima kunjungan dari siluet ini yang aku tunggu, dilengkapi dengan cambuk, tidak memungkinkan untuk melihat begitu tebal dan begitu besar. Aku memukul mereka karena aku tahu bahwa aku tidak akan pernah seperti mereka, aku tidak dapat seperti mereka... Itu untukku sebuah degenerasi yang tidak dapat diterima."
\end{abstract}

Adapun ibunya, tingkah lakunya lebih rumit. Ahmed (Zahra) benar-benar menyangkal hal tersebut. Dia mengabaikannya seperti dia telah diabaikan dan menyerahkan ibunya pada ayahnya sebagai pembalasannya. Ahmed adalah wanita yang tumbuh sebagai pria, berpikir seperti pria dan dinilai sebagai pria yang menjelaskan perilakunya tidak hanya pada ibunya dan saudarasaudaranya, tetapi juga dalam diri sendiri. Dia menganggap dirinya lebih unggul dari wanita, tidak ragu untuk penyalahgunaan dan penyiksaan. L'Enfant de Sable digambarkan sebagai berikut:

"C'est un enfant rêveur et intelligent. Il a vite compris que la société préfère les hommes aux femmes."

"C'est vrai! Dans cette famille, les femmes s'enroulent dans un linceul de silence..., elles obéissent..., mes soeurs 
obéissent; toi ( c'est-à-dire la mère), tu te tais et moi, j'ordonne!"

"Itu seorang anak pemimpi dan pandai. Dia paham dengan cepat perusahaan lebih suka laki-laki dibandingkan perempuan."

"Itu benar! Di keluarga ini, para wanita yang terbungkus kain kafan keheningan..., mereka mentaati..., saudara-saudara perempuanku taat, kamu (yaitu ibu), kamu tutup mulutmu dan aku, aku menerima."

Setiap mengikuti muslihat ayahnya, Ahmed tidak dapat berhenti untuk memikirkan identitas gandanya. Dia mengalami beberapa kebingungan dan pertentangan ketika mencoba untuk menemukan keseimbangan antara kedua belah pihak. Apakah dia akan menjadi diri sendiri ataukah mempertahankan kebebasannya dengan statusnya sebagai seorang pria. Dia mengatakan,

“...je suis et je ne suis pas cette voix qui s'accommode et prend le pli de mon corps, mon visage enroulé dans le voile de cette voix, est-elle de moi ou est-ce celle du père qui l'aurait insufflée, ou simplement déposée pendant que je dormais en me faisant $d u$ bouche à bouche?"

"J'ai perdu la langue de mon corps, d'ailleurs, je ne l'ai jamais possédée. Je devrais l'apprendre et commencer d'abord par parler comme une femme. Comme une femme? Pourquoi ? suis-je un homme?"

"...aku dan aku bukan suara yang menyesuaikan itu dan melipat tubuhku, wajahku terbungkus penutup suara ini, dia adalah milikku atau apakah ayah yang meniupkannya, atau hanya bersaksi sementara aku tidur sambil melakukannya dari mulut ke mulut ?"

"Aku kehilangan bahasa tubuhku, Selain itu, saya tidak pernah memilkinya. Aku harus belajar dan mulai dari awal dengan berbicara seperti seorang wanita. Sebagai seorang wanita? Mengapa? Saya seorang pria ?"
Di sisi lain, Ahmed berada di jalan buntu. Dia tidak mampu memutuskannya sehingga dia menyangkal dan menutupinya.

"Aujourd'hui je cherche à me délivrer. De quoi au juste ?... De cette relation avec l'autre en moi, celui qui m'écrit et me donne l'étrange impression d'être encore de ce monde?"

"Hari ini aku mencari kebebasanku. Apa saja ? ... Hubungan ini dengan yang lain dalam diriku, orang yang menulis kepada saya dan memberi saya kesan asing yang masih di dunia ini."

Suatu hari Ahmed berencana untuk mengadopsi seorang anak. Mengadopsi anak berhubungan dengan sisi feminin nya, sambil istirahat dengan kewanitaannya dan menikah dengan sepupunya, Fatima. Pernikahan ini dimaksudkan untuk memperkuat status laki-lakinya, penampilan dan identitas sosial, bahkan jika Ahmed memiliki alasan lain untuk menikah dengannya, yaitu untuk mengabaikan ketidakpedulian keluarganya dan membalas dendam pada pamannya. Memang, identitas feminin Ahmed menyerupai keinginan bawah sadarnya.

"Je sais, dans ce pays, une femme seule, est destinée à tous les refus. Dans une société morale, bien structurée, non seulement chacun est à sa place, mais il $n$ 'y a absolument pas de place pour celui ou celle, surtout celle qui, par volonté ou par erreur, par esprit rebelle, ou par inconscience, trahit l'ordre. Une femme seule, célibataire ou divorcée, une fillemère, est un être exposé à tous les rejets."

"Aku tahu, di negara ini, seorang wanita lajang, ditujukan untuk semua penolakan. Dalam masyarakat, terstruktur dengan baik, tidak hanya masing-masing yang memiliki tempatnya, tetapi benar-benar tidak ada tempat untuk mereka, terutama dia yang, berkeinginan atau bersalah, dengan semangat memberontak, atau ketidaksadaran, menghianati ketertiban. 
Seorang wanita lajang, belum menikah atau bercerai, anak-ibu, menguraikan semua penolakannya."

Pada akhirnya, Abu-Zahra
memutuskan untuk meluruskan
kebohongannya yang selama ini telah
menyerang hidupnya dan terlahir
kembali menjadi diri sendiri hingga
menemukan kedamaian.

"Je voudrais sortir pour naître de nouveau, naître à vingt-cinq ans, sans parents, sans famille, mais avec un prénom de femme, avec un corps de femme débarrassé à jamais de tous ces mensonges. Je ne vivrai peut-être pas longtemps. Je sais que mon destin est voué à être brutalement interrompu parce que j'ai, un peu malgré moi, joué à tromper Dieu et ses prophètes. Pas mon père dont je n'étais en fait que l'instrument, l'occasion d'une vengeance, le défi à la malédiction."

"Aku ingin untuk dilahirkan kembali, lahir di dua puluh lima tahun, tanpa orang tua, tanpa keluarga, tetapi dengan nama istri, dengan tubuh wanita selamanya menyingkirkan semua kebohongan ini. Aku mungkin tidak akan hidup lama. Aku tahu bahwa nasibku ditakdirkan untuk menjadi brutal terganggu karena aku memiliki sedikit, bermain untuk menipu Tuhan dan nabiNya. Tidak ayahku yang tidak kubuat pelajaran, kesempatan balas dendam, tantangan mengutuk."

Ayah dari Ahmed-Zahra mewakili kelompok laki-laki dengan mentalitas mundur. Ia mencoba untuk menyingkirkan putrinya, tapi agama melarang itu. Dari tokoh Ahmed tersebut menunjukkan belas kasihan pada perempuan, melakukan protes melawan orang-orang yang tidak berhenti menghina kaum perempuan.

"Vous savez combien notre société est injuste avec les femmes, combien notre religion favorise l'homme, vous savez que pour vivre selon ses choix et ses désirs, il faut du pouvoir. Vous avez pris goût aux privilèges et vous avez, sans peut-être le vouloir, ignoré, méprisé vos soeurs."

"Kau tahu bagaimana masyarakat kita tidak adil dengan perempuan, berapa agama kita mengutamakan laki-laki, kau tahu itu untuk hidup sesuai dengan pilihan dan harapannya, kekuasaan mereka. Anda telah berkeinginan untuk hak-hak istimewa dan Anda memiliki, tanpa sadar mungkin, diabaikan, membenci saudara Anda."

"Sachez, ami, que la famille telle qu'elle existe dans nos pays, avec le père toutpuissant et les femmes reléguées à la domesticité avec une parcelle d'autorité que leur laisse le mâle, la famille, je la répudie, je l'enveloppe de brume et ne la reconnais plus."

"Menyadari, teman, keluarga seperti yang ada di negara kita, dengan ayah mahakuasa dan degradasi perempuan sebagai pembantu dengan sebidang otoritas yang meninggalkan kejantanan mereka, keluarga, saya menolak, saya menyelubungi kabut dan tidak mengenalnya lagi."

Di sisi lain, sang ibu juga pada dasarnya ingin memberontak atas perilaku suaminya. Namun, dirinya tidak mampu mengungkapkannya dan memilih untuk diam sebagai seorang istri dan ibu. Karena dengan memilih diam, dia tersedak naluri keibuan terhadap anaknya, naluri yang biasanya mendorong ibu untuk melindungi anaknya dan membela kepentingan mereka.

L'Enfant de Sable sendiri berlangsung di awal abad 20 di Maroko pada masa poskolonial. Secara khusus perlakuan terhadap perempuan di Maroko berada di bawah pengawasan. Sementara kisah di tahun 1950-an, merespons banyak cara perlakuan terhadap perempuan. Pada tahun 1956 Raja Mohammed V menyatakan kemerdekaan untuk Maroko dari Prancis dan beliau dikenal sebagai pemimpin yang cukup maju. Kemudian pada tahun 
1961 Hassan II mengambil alih dan kembali pada tradisi-tradisi yang sangat konservatif dalam periode yang dikenal sebagai "Tahun Tangan Besi". Periode ini ditandai dengan kekerasan terhadap perempuan dan anak perempuan. Banyak yang telah berubah sejak Mohammed VI mengambil alih pada tahun 1999. L'enfant de Sable berlangsung sebagai fokus keyakinan bahwa pada awal abad pertengahan di Maroko anak laki-laki lebih berharga daripada anak perempuan. Hal ini jelas terungkap ketika Ayah Ahmed merasa malu bahwa dia tidak memiiki anak laki-laki sehingga menyembunyikan identitas Ahmed yang sebenarnya.

\section{PENUTUP}

Dari apa yang terjadi dalam roman ini dapat terlihat bahwa orang tua memiliki peranan yang sangat penting dalam sebuah keluarga, terutama bagi anak-anaknya. Seorang ayah sebagai seorang pemimpin keluarga dianggap sebagai pemegang kekuasaan mutlak dan seorang anak harus mematuhi apa pun yang diperintahkan orang tua kepadanya sebagai sebuah bentuk kepatuhan. Kisah kehidupan Ahmed merupakan cerminan dari hal tersebut. Pengaruh dari kepercayaan masyarakat yang mengagungkan laki-laki mendasari perbuatan yang dilakukan oleh Hadj Ahmed terhadap tokoh utama.

Paparan di atas merupakan cerminan adanya budaya patriarki yang dianut oleh masyarakat Maroko dalam cerita L'Enfant de Sable. Kepercayaan masyarakat pada budaya tersebut memunculkan terjadinya ketidaksetaraan gender antara laki-laki dan perempuan. Laki-laki sangat diagungkan dan perempuan menjadi sosok yang tersubordinasi. Dapat disimpulkan bahwa nilai-nilai patriarkal dan ketidak-setaraan gender yang tercermin dalam roman L'Enfant de Sable karya Tahar Ben Jelloun adalah sebagai berikut. (1) Laki- laki lebih superior dibandingkan perempuan. (2) Posisi laki-laki selalu dianggap lebih penting dibandingkan perempuan. (3) Keberadaan nilai-nilai patriarkal memunculkan stigma negatif mengenai perempuan, seperti memiliki anak perempuan menimbulkan rasa malu bagi keluarga, domestifikasi terhadap perempuan, perempuan dianggap sebagai sosok yang hanya bisa menghambur-hamburkan uang dan serentetan sifat dan perilaku yang diberikan kepada perempuan karena memiliki rahim. (4) Kedudukan perempuan sebagai kelas kedua.

Ketidaksetaraan gender sangat memengaruhi tokoh utama dalam roman L'Enfant de sable karya Tahar Ben Jelloun. Hal itu dibuktikan dengan ketidakmampuan tokoh utama untuk menampilkan identitas sebenarnya sebagai seorang perempuan selama di bawah kekuasaan sang ayah. Selain itu, tokoh utama, Ahmed, dapat melihat betapa di dalam masyarakat, ketidaksetaraan gender begitu kuat. Sebagai seorang laki-laki tokoh utama hadir sebagai seorang pewaris dan harapan keluarga, sedangkan sebagai perempuan tokoh utama adalah mimpi buruk bagi sang ayah, bahkan bagi dirinya sendiri.

\section{DAFTAR PUSTAKA}

Arikunto, S. (2005). Prosedur penelitian Suatu Pendekatan Praktek. Jakarta: Penerbit Salemba Empat.

Ben Jelloun, T. (1978a), La Nuit Sacrée. Paris: Editions du Seuil.

Ben Jelloun, T. (1995). L'Enfant de Sable. Paris: Editions du Seuil.

Cixous, H., Cohen, K., \& Cohen, P. (1976). The Laugh of the Medusa. Signs, 1(4), 875-893.

Combe, D. (2010). Les Littératures Francophones, Questions, Débats, Polémiques. Paris: Presses Universitaires de France. 
Dechaufour, L. (2008). Introduction au Féminisme Poscolonial. Nouvelles Questions Feministes Vo. 27. Page 152. ISBN: 9782889010158.

Gilligan, C., \& Richards, D. A. J. (2009). The Deepening Darkness: Patriarchy, Resistance, and Democracy's Future. New York: Cambridge University Press.

Gilligan, C. (2008a). Kyra: A novel.

New York: Random House.

Gilligan, C. (2004b) Knowing and not knowing: Reflections on manhood. Psychotherapy and Politics International, 2 (2), 99-114

Rahmawati, I. (2015). Realitas Poskolonialisme dalam Roman L'Homme Rompu Karya Tahar Ben Jelloun. Journal of Lingua Litteratia. Sastra Prancis UNNES.

Shusha, G. (1999). Tahar Ben Jelloun, The Art of Fiction. Paris: The Paris Revieuw. 